\title{
EDITORIAL \\ Research in global neurosurgery: informing the path to achieving neurosurgical equity
}

\author{
Kee B. Park, MD \\ Global Neurosurgery Initiative, Program in Global Surgery and Social Change, Department of Global Health and Social \\ Medicine, Harvard Medical School, Boston, Massachusetts
}

I $\mathrm{N}$ response to the 2015 landmark report of the Lancet Commission on Global Surgery, ${ }^{5}$ neurosurgeons began to organize to address the disparities in neurosurgical access and care in the developing world. The extraordinary ascent of the global neurosurgery movement is now being emulated by other surgical specialties. ${ }^{10}$ The surge in research output is one key factor in the success of the movement (Fig. 1).

Our initial baseline research is presented in this issue of the Journal of Neurosurgery. By framing and defining the problem at the global level, we challenged the leaders of organized neurosurgery to tackle the massive neurosurgical inequities in the developing world.

We first established the current global neurosurgical workforce. There are 49,940 neurosurgeons globally, and the Sub-Saharan Africa and South and Southeast Asia regions have the lowest densities. ${ }^{6}$ Using a survey, we estimated that, on average, a neurosurgeon performs 245 cases annually. ${ }^{1}$ We then performed systematic reviews to estimate the total incidence of major neurosurgical conditions. For example, Vaughan et al. showed that up to 1.4 million new surgical cases of epilepsy occur each year, mostly in low- and middle-income countries (LMICs). ${ }^{9}$ Dewan et al. estimated the annual global incidence of traumatic brain injuries (TBIs) to be 69 million. ${ }^{3}$ Of note, LMICs “...experience nearly 3 times more cases of TBI proportionally..." than high-income countries. Dewan et al. also estimated the annual incidence of pediatric hydrocephalus to be 400,000 cases, with the highest burden in Africa, Latin America, and Southeast Asia. ${ }^{4}$ Furthermore, the systematic review by Robertson et al. showed that almost 1 million operations are needed for the treatment of CNS infections?

In our executive summary, the incidences from these studies and others were mapped along with the current neurosurgical capacity by regions, and by income levels.
We now know that the unmet need for essential neurosurgical cases exceeds 5 million per year and that 23,300 additional neurosurgeons are needed to meet the current demand. Not surprisingly, the needs are greatest in SubSaharan Africa and South and Southeast Asia. ${ }^{2}$

Last, Rudolfson et al. showed that, just in the 90 LMICs, neurosurgical conditions, largely unmet at present, will result in $\$ 4.4$ trillion in cumulative gross domestic product losses by $2030 .^{8}$

Taken collectively, there is a compelling moral, ethical, and economical argument for the neurosurgical community to work alongside the global surgery community and development partners to advocate for strengthening emergency and essential surgical care in the LMICs. Future research in global neurosurgery is urgently needed as neurosurgeons are increasingly being asked to provide technical and strategic guidance to policymakers in building capacity to meet the global neurosurgical workforce and case deficit. As such, we should try to answer questions as they pertain to improving the delivery of emergency and

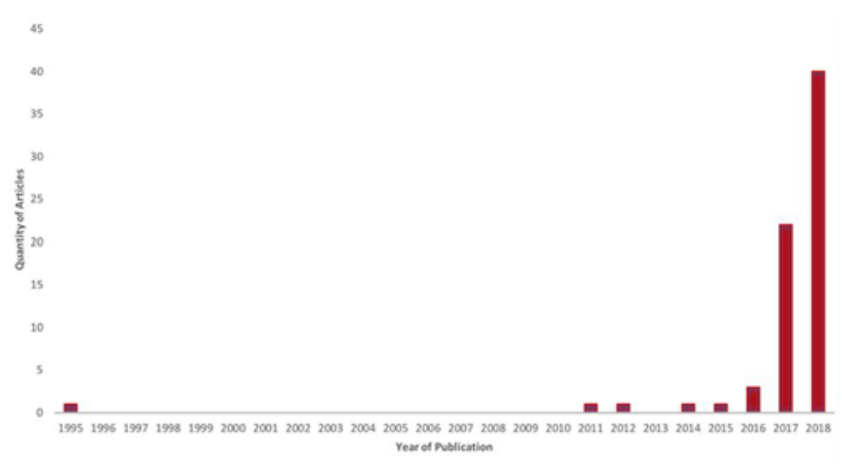

FIG. 1. Graph showing results of a PubMed search of "global neurosurgery" accessed January 2019. Figure is available in color online only. 
essential neurosurgical services such as TBI and to complementing service delivery through innovative ways to deliver care and manage patients in low-resource settings. https://thejns.org/doi/abs/10.3171/2019.2.JNS19295

\section{References}

1. Dewan MC, Rattani A, Baticulon RE, Faruque S, Johnson WD, Dempsey RJ, et al: Operative and consultative proportions of neurosurgical disease worldwide: estimation from the surgeon perspective. J Neurosurg [epub ahead of print May 11, 2018; DOI: 10.3171/2017.10.JNS17347]

2. Dewan MC, Rattani A, Fieggen G, Arraez MA, Servadei F, Boop FA, et al: Global neurosurgery: the current capacity and deficit in the provision of essential neurosurgical care. Executive Summary of the Global Neurosurgery Initiative at the Program in Global Surgery and Social Change. J Neurosurg [epub ahead of print April 27, 2018; DOI: 10.3171/2017.11.JNS171500]

3. Dewan MC, Rattani A, Gupta S, Baticulon RE, Hung YC, Punchak M, et al: Estimating the global incidence of traumatic brain injury. J Neurosurg [epub ahead of print April 27, 2018; DOI: 10.3171/2017.10.JNS17352]

4. Dewan MC, Rattani A, Mekary R, Glancz LJ, Yunusa I, Baticulon RE, et al: Global hydrocephalus epidemiology and incidence: systematic review and meta-analysis. J Neurosurg [epub ahead of print April 27, 2018; DOI: 10.3171/2017.10. JNS17439]

5. Meara JG, Leather AJ, Hagander L, Alkire BC, Alonso N, Ameh EA, et al: Global Surgery 2030: evidence and solutions for achieving health, welfare, and economic development. Lancet 386:569-624, 2015

6. Mukhopadhyay S, Punchak M, Rattani A, Hung YC, Dahm J, Faruque S, et al: The global neurosurgical workforce: a mixed-methods assessment of density and growth. $\mathbf{J}$ Neurosurg [epub ahead of print January 4, 2019; DOI: 10.3171/2018.10.JNS171723]
7. Robertson FC, Lepard JR, Mekary RA, Davis MC, Yunusa I, Gormley WB, et al: Epidemiology of central nervous system infectious diseases: a meta-analysis and systematic review with implications for neurosurgeons worldwide. J Neurosurg [epub ahead of print June 15, 2018; DOI: 10.3171/2017.10.JNS17359]

8. Rudolfson N, Dewan MC, Park KB, Shrime MG, Meara JG, Alkire BC: The economic consequences of neurosurgical disease in low- and middle-income countries. J Neurosurg [epub ahead of print May 18, 2018; DOI: 10.3171/2017.12. JNS17281]

9. Vaughan KA, Lopez Ramos C, Buch VP, Mekary RA, Amundson JR, Shah M, et al: An estimation of global volume of surgically treatable epilepsy based on a systematic review and meta-analysis of epilepsy. J Neurosurg [epub ahead of print September 14, 2018; DOI: 10.3171/2018.3.JNS171722]

10. Vervoort D, Park KB, Swain JD: Global cardiac surgery: lessons learnt from the global neurosurgery movement. Heart Asia 11:e011125, 2019

\section{Disclosures}

The author reports no conflict of interest.

\section{Correspondence}

Kee B.Park: keepark@yahoo.com.

\section{INCLUDE WHEN CITING}

DOI: 10.3171/2019.2.JNS19295. 